Article

\title{
Cross the Border: Participative Integrated Approach to Sustainable Tourism Planning
}

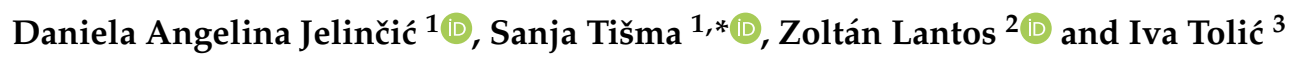 \\ 1 Institute for Development and International Relations IRMO, 10000 Zagreb, Croatia; daniela@irmo.hr \\ 2 Institute of Advanced Studies Kőszeg (iASK), 9730 Koszeg, Hungary; zoltan.lantos@iask.hu \\ 3 Institute for Development and International Relations IRMO, 10000 Zagreb, Croatia; itolic@irmo.hr \\ * Correspondence: sanja.tisma@irmo.hr
}

Received: 27 August 2019; Accepted: 3 October 2019; Published: 8 October 2019

\begin{abstract}
Cross-border areas and cross-border cooperation are one of the priorities of the EU policy. Those areas, often rich in recreational, cultural and natural resources provide a great potential for the development of sustainable tourism. The article analyzes the tourism in the Croatian-Hungarian (HR-HU) cross-border area under the assumption that different interventions can influence the perception of tourists and contribute to the realization of the full potential of the area. The method applied in the analysis is the gravity model. The results obtained by the model were tested with online in-depth interviews with three experts having backgrounds in entrepreneurship, decision making and the non-governmental sector, and focus groups, consisting of 31 experts in the field, show that altogether $72 \%$ of the tourists cross the border during a trip to the HR-HU border regions. Almost half of the respondents plan and organize programs during the trip. The main sources of collecting information about a trip are friends, family members and acquaintances, while $80 \%$ of the respondents also use at least one online tool for planning of the trip. In order to improve tourism indicators in the Croatian-Hungarian cross-border area, development of a cross-border online platform is being envisaged that would integrate different services and attractions, collect and utilize data, being the most important new raw material, thus opening a completely new space for virtual tourism.
\end{abstract}

Keywords: cross-border cooperation; economic development; tourism planning; integrated tourism offer; gravity model in tourism

\section{Introduction}

Cross-border areas are one of the priorities of the European Union (EU) policy and cross-border cooperation has been stimulated by the EU for 25 years via the EU Interreg Program. Although cross-border areas are often rich in recreational, cultural and natural resources for sustainable tourism development, they rarely provide integrated common packages [1]. Moreover, cross-border cooperation in tourism development is often shed by the competitive pressures, which force each side of the border to draw tourists instead of investing in cooperation [2]. Lack of cooperation often leads to poor presentation of tourism attractions in the local communities' tourism offer and the Croatian-Hungarian border is not an exception. Regarding the economic, social and cultural potential of these attractions near the border, their poor exploitation cases not just missed revenue but also rather low-level of cultivation of the existing values decreasing the social resilience of the region. The studied border includes three counties on the Hungarian side (Zala, Somogy and Baranya) and four on the Croatian side (Međimurje, Koprivnica-Križevci, Virovitica-Podravina and Osijek-Baranja Counties; see Figure 1). 


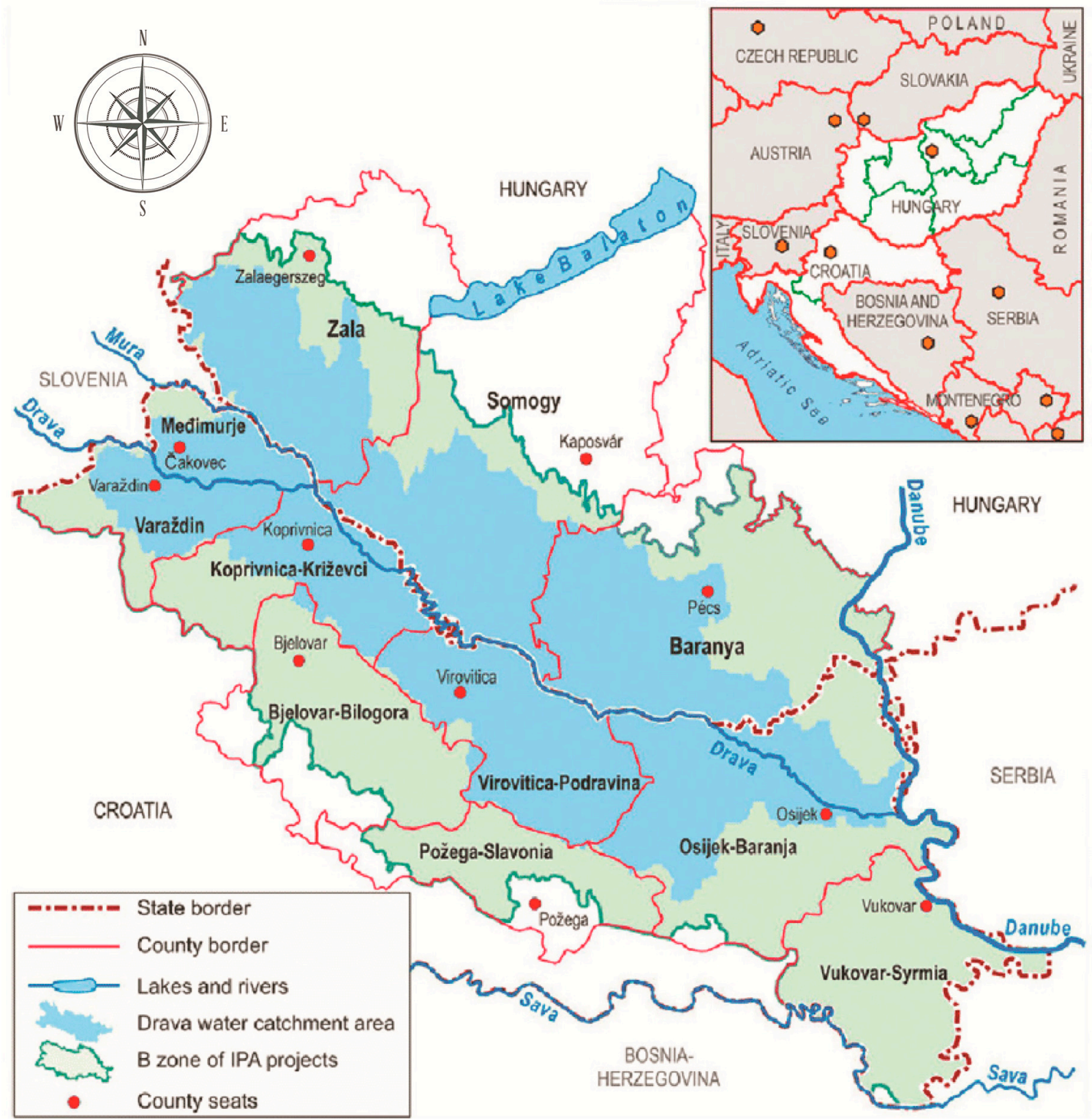

Figure 1. Croatian-Hungarian border regions [3].

It is not easy to analyze the border region as a whole due to the fact that on both sides it is divided into separate administrative centers (counties). Therefore, analysis, statistical processing and regional policies cannot be easily presented as applying to the entire border region. They should rather be presented in accordance with county division. On the other hand, the border area can be seen as one region to which all national laws and regulations are equally applied and where one county can be seen as a representative of the whole region in international projects or joint cross-border events. Thus, examples of cross-border cooperation fields, good practices, joint projects and events may be considered as referring to the whole area, while detailed assessment of the state-of-play of cross-border tourism shows differences in the various parts of the border, depending on the county. As a consequence of the above mentioned country specific efforts [2], the closer we are to the border and further from the major national tourism attractions, the less resources are put on presentation. The collected county specific data reflect that situation.

Tourism in the Croatian border counties is mostly based on recreation and sports, health tourism, cultural tourism, gastronomy and oenology, business tourism and ecotourism. In 2017, 195,297 tourists visited the counties on the Croatian side of the border. Most of the tourist arrivals were in Osijek-Baranja 
County (92,239 arrivals) and Međimurje County (70,337 arrivals), whereas Koprivnica-Križevci and Virovitica-Podravina Counties are much less visited (18,537 tourist arrivals and 14,184 respectively in 2017). Over-night stays reflect the county tourist visitations: Osijek-Baranja County leads with 177,677 over-night stays and Međimurje follows with 168,146. Koprivnica-Križevci County counts 38,814 over-night stays while Virovitica-Podravina County counts 33,453. Although Osijek-Baranja County is the most visited, the length of tourist over-night stays there is the shortest (av. 1.92 nights). Međimurje leads in this respect with the average of 2.39 over-night stays, followed by Virovitica-Podravina (av. 2.35) and Koprivnica-Križevci Counties (av. 2.09) [4,5] (see Table 1).

Table 1. Tourist arrivals and over-night stays in the Croatian-Hungarian border area in 2017.

\begin{tabular}{ccc}
\hline County & Tourist Arrivals & Tourist over-Night Stays \\
\hline CROATIA & & \\
\hline Osijek-Baranja & 92,239 & 177,677 \\
Međimurje & 70.337 & 168,146 \\
Koprivnica-Križevci & 18,537 & 38,814 \\
Virovitica-Podravina & 14,184 & 33,453 \\
TOTAL & 195,297 & 418,090 \\
\hline HUNGARY & & \\
Zala County & 749,100 & $2,693,100$ \\
Somogy & 646,700 & $1,799,700$ \\
Baranya & 309,100 & 702,800 \\
TOTAL & $1,704,900$ & $5,195,600$ \\
\hline
\end{tabular}

Source: Croatian Bureau of Statistics and Central Bureau of Statistics, Hungary.

The analysis of tourism on the Hungarian side shows strong tourism activities in Somogy (646,700 tourist arrivals in 2017) and Zala Counties (749,100 tourist arrivals in 2017), mainly due to the several resorts of these counties at lake Balaton; and Zala is also strong on thermal spas (Hévíz, Zalakaros). Baranya attracts much less tourists (309,100 tourist arrivals in 2017). Tourist over-night stays in 2017 reflect the county tourist visitations: Zala County leads with 2,693,100 over-night stays, Somogy follows with 1,799,700, while Baranya counts 702,800 over-night stays. The length of over-night stays also reflects the characteristic of attractions in the three counties. Zala county, with several well-established thermal spas and with Lake Balaton, has the longest over-night stay (av. 3.59 nights), Somogy with Lake Balaton follows (av. 2.78 nights) and Baranya has the shortest over-night stay (av. 2.27).

The total number of beds in Croatia in 2017 according to Table 2 shows that Osijek-Baranja County is leading with 2511 beds, and Međimurje County follows with 1538 beds. However, Virovitica-Podravina County has more available beds (705) than Koprivnica-Križevci County (676), although having less tourist arrivals and over-night stays. Number of beds in hotels in 2017 was as follows: Osijek-Baranja County-951 available beds, Međimurje-606, Koprivnica-Križevci County—357 and Virovitica-Podravina County-141. The total number of beds, however, has decreased (2017/2016) for the counties of Osijek-Baranja $(-5.64 \%)$ and Koprivnica-Križevci County $(-7.4 \%)$, whereas the increase is noted for the counties of Međimurje $(+13.17 \%)$ and Virovitica-Podravina $(+15.76 \%)$.

The total number of beds in 2017 follows somewhat different pattern in the Hungarian side of the border with Somogy County leading with 48,827 beds, while Zala has 26,654 beds, since there are many registered bed services at the long Balaton shore in Somogy. However, the occupancy rate is rather low. Number of beds in hotels in 2017 is the highest in Zala County $(14,271)$ following the actual market potential, Somogy has almost the same amount $(14,123)$ and Baranya has substantially less $(4564)$.

The general number of tourist activities in all four counties in Croatia is not high, although it is much higher on the Hungarian than on the Croatian side. Continental parts of Croatia are still seeking to introduce selective types of tourism in order to follow the continuously growing tourism trends on the Croatian seaside. A number of developmental activities relating to continental tourism are also detected in the Croatian Tourism Development Strategy 2020 [6]. Therefore, all counties would benefit 
from the tourism increase. Additionally, all counties, but especially Osijek-Baranja County would benefit from the increase in the length of stay. The existing offer across all four counties focuses on different products and services related to cultural and natural resources, recreation/sports, health and business tourism with an indispensable gastronomy offer.

Table 2. Total number of beds and number of beds in hotels in cross-border area, 2016-2017.

\begin{tabular}{ccccc}
\hline \multirow{2}{*}{ County } & \multicolumn{2}{c}{ Total Number of Beds } & \multicolumn{2}{c}{ Number of Beds in Hotels } \\
\cline { 2 - 5 } & $\mathbf{2 0 1 6}$ & $\mathbf{2 0 1 7}$ & $\mathbf{2 0 1 6}$ & $\mathbf{2 0 1 7}$ \\
\hline CROATIA & & & & \\
\hline Koprivnica-Križevci & 730 & 676 & 357 & 357 \\
Virovitica-Podravina & 609 & 705 & 141 & 141 \\
Osijek-Baranja & 2661 & 2511 & 1185 & 951 \\
Međimurje & 1359 & 1538 & 576 & 606 \\
TOTAL & 5359 & 5430 & 2259 & 2055 \\
\hline HUNGARY & & & & \\
\hline Baranya & 12,566 & 11,517 & 4809 & 4564 \\
Somogy & 78,441 & 48,827 & 14,576 & 14,123 \\
Zala & 27,512 & 26,654 & 13,903 & 14,271 \\
TOTAL & 118,519 & 86,998 & 33,288 & 32,958 \\
\hline
\end{tabular}

Source: Croatian Bureau of Statistics and Central Bureau of Statistics, Hungary.

On the Hungarian part of the border area, the three different counties put the main focus on different products and services-Zala on spas, Somogy on lake Balaton, Baranya on the City of Pécs and the Villány wine region. Table 3 shows that all counties have capacities and resources for the development of diverse tourism offer, which could be further expanded.

Table 3. Services offered in the cross-border region.

\begin{tabular}{|c|c|c|c|c|c|c|c|}
\hline \multirow[b]{2}{*}{$\begin{array}{l}\text { Main Types } \\
\text { of Services: }\end{array}$} & \multicolumn{4}{|c|}{ CROATIA } & \multicolumn{3}{|c|}{ HUNGARY } \\
\hline & $\begin{array}{c}\text { County of } \\
\text { Međimurje }\end{array}$ & $\begin{array}{l}\text { County of } \\
\text { Koprivnica- } \\
\text { Križevci }\end{array}$ & $\begin{array}{l}\text { County of } \\
\text { Virovitica- } \\
\text { Podravina }\end{array}$ & $\begin{array}{c}\text { County of } \\
\text { Osijek- } \\
\text { Baranja }\end{array}$ & $\begin{array}{c}\text { County of } \\
\text { Baranya }\end{array}$ & $\begin{array}{l}\text { County of } \\
\text { Somogy }\end{array}$ & $\begin{array}{c}\text { County of } \\
\text { Zala }\end{array}$ \\
\hline $\begin{array}{l}\text { Recreation } \\
\text { and sports }\end{array}$ & $\times$ & $x$ & $\times$ & $x$ & & $\times$ & $\times$ \\
\hline $\begin{array}{l}\text { Health } \\
\text { tourism }\end{array}$ & $x$ & & $x$ & & $x$ & $\times$ & $x$ \\
\hline $\begin{array}{l}\text { Cultural } \\
\text { tourism }\end{array}$ & $x$ & $x$ & $x$ & $x$ & $x$ & & $x$ \\
\hline $\begin{array}{l}\text { Gastronomy } \\
\text { and oenology }\end{array}$ & $x$ & $x$ & & $x$ & $x$ & $x$ & $x$ \\
\hline $\begin{array}{l}\text { Business } \\
\text { tourism }\end{array}$ & $x$ & & & $\times$ & $\times$ & $x$ & $x$ \\
\hline Ecotourism & & $x$ & $x$ & $x$ & & $x$ & $x$ \\
\hline
\end{tabular}

Source: Authors based on desk research and interviews (see 2. Materials and Methods).

Previous research on opportunities and obstacles to Croatian-Hungarian (HR-HU) cross-border cooperation [7] analyzed the bilateral trade flows approximation by the gravity model for two specific counties: Somogy County and Virovitica-Podravina County, which belong to less developed counties in the analyzed region along the border of both countries. According to the results, although there is cooperation in the cross-border area, the key weaknesses for cross-border cooperation include a lack of transport connections and language barrier, while strengths reflect the entrepreneurial spirit and opportunity to apply and implement joint entrepreneurial projects financed by the EU funds.

Tourism programs in the HR-HU cross-border cooperation have not been analyzed in the mentioned research, although there is a strategic planning framework in both countries' initial 
documents and cross-border programs. Besides, there are no other recent scientific analysis on the cross-border sustainable tourism activities and cooperation in the Croatian-Hungarian border area. Since the Croatian Tourism Development Strategy by 2020 envisions Croatian integration into the EU consolidated tourism policy, international cooperation is of key importance, especially bilateral cooperation between the countries of shared interests for mutual satisfaction and benefit. In the National Tourism Development Strategy of Hungary 2030 [8], a detailed strategic tool set puts special emphasis on the extension of the Hungarian border regions with the transborder attraction. The HR-HU cross-border cooperation was supported by the EU through the IPA Cross-border Cooperation Program in the period 2007-2013. The Hungary-Croatia IPA Cross-border Co-operation Program 2007-2013 was approved by the European Commission on March 13, 2008. The program allocated $€ 52,433,025$ of community funding for seven years [9]. The first priority of the program was sustainable environment and tourism, financed with $60 \%$ of total funds [10]. The program allocations proved to be successful in the tourism sector since. The analysis shows the increased number of tourist arrivals in the period after the program (e.g., for Osijek-Baranja County 89,386 tourist arrivals in 2008 increased to 92,239 in 2017; for Međimurje County 32,351 tourist arrivals in 2009 increased to 70,337 in 2017).

The problem of cross-border areas and tourism development is globally recognized as an important challenge for local communities along the border. Although institutional environment and language barriers remain the stumbling block for one-to-one entrepreneurial cooperation, conditions for cross-border cooperation can be enabled through common EU projects setting up frameworks for easier cooperation of interested public, private and civil actors. The sustainable tourism concept emerged from the idea of a necessary interconnection between tourism development, community participation and environmental protection [11]. In the same line, cross-border cooperation entails common strategic planning, which enables considering all relevant data for the state-of-play analysis, defining the common tourism development vision, key priorities as well as a clear action plan to be followed by actors on both sides of the border with the aim of achieving the common goal. This creates preconditions for sustainable development of the area. Besides ensuring common strategic planning, it is necessary to ensure participation of the local population in the entire process of tourism development planning. Involvement of local communities in the planning process envisions also sharing of tourism benefits by the same communities, as per the normative model of participatory tourist planning [12]. This type of planning should be based on various planning tools, such as the limits of acceptable change (LAC) [13], which defines the acceptable and desirable resources translating them into actions, which will achieve and maintain the desired state. Further tools may include the recreation opportunity spectrum (ROS) [14], tourism opportunity spectrum (TOS) [15], ecotourism opportunity spectrum (ECOS) [16], urban tourism opportunity spectrum (UTOS) [17], etc. Participatory models of tourism planning, however, do not include only local community and management structures, but should also consider the visiting tourists and their needs. The effective tool for considering these issues is the interpretation opportunity spectrum (IOS) [18].

Tourism activity in any border area can be seen as a part of bilateral trade between two countries. Bilateral trade is often analyzed using the gravity model, which evaluates tourism flows between two countries based on the GDP (gross domestic product) analysis, population, language barriers or cultural proximity and potential membership in bilateral or regional trade agreements. Theoretical foundation for gravity models in the context of tourism is offered by Morley, Rosselló and Santana-Gallego [19], who derived gravity models for tourism demand from consumer choice theory and linked models to aggregated tourism demand equations. The article also suggests estimation procedures for gravity models. Gravity models are not applicable only to the analysis of the demand for tourism in a country, but also to the examination of the impact of other variables to the touristic demand, such as transportation, events and many others. Khadaroo and Seetanah [20] evaluated the importance of transport infrastructure in determining the tourism attractiveness of destinations and found that, on top of tourism infrastructure and other classical determinants, transport infrastructure is a significant determinant of tourism inflows into a destination. The transport was also analyzed by Rey, Myro 
and Galera [21], who estimated the impact of low-cost airlines on Spanish tourism during the first decade of the 21st century and concluded that the expansion in low-cost airline activity in the tourism market had significant, positive direct and indirect effects on the Spanish economy. Using the gravity model, Fourie and Santana-Gallego [22] analyzed the impact of mega-sport events on tourist arrivals and Priego, Rosselló and Santana-Gallego [23] researched the impact of climate change on tourism in Spain. Another example of using the gravity model was made by Gil-Pareja, Llorca-Vivero and Martínez-Serrano [24] in the article that estimated the effect of the euro on intra-EMU (European Monetary Union) tourist flows by using a panel dataset of 20 OECD (Organisation for Economic Co-operation and Development) countries over the period 1995-2002. The results revealed that the euro had increased tourism, with an effect of around $6.5 \%$.

Cross-border tourism development and efforts to develop tourism across international borders have been increasing over the last few decades. Globalization and geopolitical developments are argued to have altered the function of borders, which has led to increasingly permeable borders [24]. Even though the awareness and importance of cross-border tourism increased, the researchers' interest in the subject did not grow at the same pace. Although studies on cross-border tourism exist, they rarely relate to the European context (e.g. [25-27]) or fail to relate to cross-border tourism analysis by the gravity model. For example, Huang [28] set up a theory model of entry tourism between China and Vietnam and carried out regression analysis. The result showed that variables such as nominal GDP, reception amount, geography distance and boundary had great impact on Vietnam entry tourism to China. Further analysis validated that GDP and geography distance had certain impulsion on entry tourism.

Analyzing the cultural effects on inbound tourism into the USA, Vietze [29] devoted a part of the paper to the cross-border countries-Mexico and Canada. The results provided evidence that cultural proximity between the country of origin and country of destination has positive effects on the tourism flows between those countries. In particular, after controlling for a set of geographical variables, more people from countries with the same language (English) and high governmental rankings comparable to those of the USA travel to the USA for holidays than people from other countries do. Above all, there is strong evidence that tourists from Christian countries prefer the USA as a holiday destination much more than people from other countries.

National borders were also considered in the work of Kosnan, Ismail and Kaliappan [30] who analyzed demand and supply factors in the Malaysian tourism industry. The findings reveal that major factors, which increased inbound international tourism and thus increased the tourist receipt in Malaysia were the market size for both destination and origin countries, common border, common language with Malaysia, shorter distance and lower transportation costs. On the supply side, the number of hotel rooms, quality in road infrastructure and air transport infrastructure appeared to be an important factor among international tourists.

The gravity models are used mostly for the analysis of demand for tourism in specific countries. For example, Butter, Chasapopoulos and Mihaylov [31] used gravity model to examine the main determinants of international tourism demand in Greece. Using data on tourist flows from 31 countries to Greece, the analysis showed that distance and trade ties between Greece and the sending countries were important factors influencing foreign demand for tourist services. Eryiğit, Kotil and Eryiğit [32] analyzed the factors affecting the numbers of international tourists visiting Turkey from the top 11 originating countries for 1995-2005. It was found that GDP per capita, tourism climate index, population of the originating country, tourism price index, distance, earthquake, neighboring country and 9/11 terrorist attacks could explain most of the data. These models are also popular in explaining the demand for tourism in Asian countries. For example, Hanafiah and Harun [33] analyzed the tourism demand in Malaysia, Yang and Wong [34] in China and Keum [35] in Korea.

Starting from the analysis of the situation in tourism in the HR-HU cross-border regions, the available capacities and resources for tourism development, strategic plans and possible development models, the initial assumption of this paper is that although there are factors that limit and/or complicate 
cross-border tourism, targeted action can significantly contribute to the growth of tourism activity and the number of tourists in that area. Subtle interventions on individual economic indicators that are visible through the application of the gravity model in the participatory and integrated approach to tourism offer planning in these areas could have a substantial impact on a common tourism offer, thus ensuring sustainable development of the area.

The main aim of this paper is to detect potentials for joint HR-HU cross-border tourism development through the process of the strategic, participatory and integrated planning process involving not only governance/management structures but also potential tourists. This should result in a joint ICT (infocommunication) tourism platform having impact on tourists' decisions to cross the border in search for new experiences and enhancing joint entrepreneurial activities for the common benefit. Research results provided in this paper are relevant for the development of such a joint ICT platform, which may have impact not only on the increased cross-border tourism visits but on the overall sustainable development of the whole border region, thus promoting cooperation rather than competitiveness.

\section{Materials and Methods}

The results of the research presented in this article are based on the desk analysis and data analysis further backed up with qualitative and quantitative research methods. Desk analysis included an in-depth review of the relevant scientific literature (books and articles) and available Internet sources. For the purpose of gathering the results of the relevant scientific research, scientific research platforms (e.g., Google Scholar, Science Direct, Social Science Premium Collection ProQuest, Springer Journals and Taylor and Francis) were extensively searched by key words such as sustainable tourism, cross-border cooperation "the gravity model in tourism", sustainable tourism and "cross-border tourism planning". The data analysis included collecting, processing and interpreting the trends of tourists' flows between Croatia and the surrounding countries (Italy, Slovenia, Hungary, Austria, Bosnia and Herzegovina and Serbia). For these purposes, relevant current statistical databases published by European Statistical Office (Eurostat), the Hungarian Bureau of Statistics and the Croatian Bureau of Statistics were also used.

To analyze the cross-border tourism with gravity model, the feasible generalized least squares (FGLS) estimation method was used because of the inclusion of distance in the model as a size variable, which could give rise to heteroscedasticity. The gravity model in tourism for econometric estimation used in the study was [29]:

$$
\ln T A_{i j t}=\alpha_{i}+\lambda_{j}+\delta_{t}+\beta_{1} \ln Y_{i t}+\beta_{2} \ln Y_{j t}+\beta_{3} \ln D_{i j}+\beta_{i j t} A_{i j t}+u_{i j t}
$$

where $T A_{i j t}$ is a dependent variable that represents the total amount of tourists traveling from country $i$ to country $\mathrm{j}$ in the year $\mathrm{t}, Y_{i t}$ is the absolute GDP in the country of origin $i$ in year $t, Y_{j t}$ the absolute GDP in the country of destination $j$ in year $t, D_{i j}$ the geographical distance between the capitals or economic centers of countries $i$ and $j$ and $A_{i j t}$ are additional explanatory variables with variation in all three dimensions, $i, j$ and $t$. The variables $\alpha_{i}, \lambda_{j}$ and $\delta_{t}$ represent the country (country of origin $i$ and country of destination $j$ ), respectively the time fixed effects as well as $u_{i j t}$ represents the white noise disturbance term.

The results of the quantitative statistical hard data search and results of the gravity model analysis were additionally supplemented with the qualitative and questionnaire-based quantitative research methods out of which in-depth interviews, online survey and structured workshops. Qualitative part of the research was conducted within the BorderPass project, co-funded under the call HUHR/1001 of the Hungary-Croatia Cross-border Cooperation Program in the period from 1 October 2011 to 31 January 2013 [9]. The inclusion of non-quantitative factors in the research, such as individual perceptions and experiences, was important for greater understanding of the cross-border entrepreneurial cooperation. Three key local stakeholders on both sides of the border (entrepreneur, decision maker and representative of the non-governmental sector) were recruited, and 50-60 minutes long in-depth phone interviews 
were conducted with them during December 2018 and January 2019. Quantitative online CAWI research was conducted with the aim to get to know travelling habits regarding Hungarian-Croatian border regions, the information collection schemes about the regions and trip planning, and to find out people's opinion on the potential development of BorderPass info-communication platform. Sample size was 80 people in Croatia and 80 people in Hungary, aged 18-65, who visited the HR-HU border region in the past 5 years for holiday purposes. The interview consisted of 16 questions grouped around the previously mentioned topics.

The two focus groups were organized (in Kőszeg in November 2018 and in Zagreb in January 2019) to stimulate the participatory approach in defining key guidelines for strengthening future cross-border cooperation in tourism and future options. The first focus groups included 13 participants and the second one 18 of them. Participants were selected according to their expertise in tourism and their area of work in the bordering regions. Thus, representatives of the academic, education and non-governmental sector were involved as well as business professionals, professionals in tourism (tourism boards) and regional development (local and regional development agencies). The results of the gravity model and interviews were presented to the participants, mainly the key decision-makers in cross-border region. The results were also analyzed, discussed and the recommendations were developed.

\section{Results}

As previously mentioned, the analyzed border region includes three counties on the Hungarian side (Zala, Somogy and Baranya) and four on the Croatian side (counties of Međimurje, Koprivnica-Križevci, Virovitica-Podravina and Osijek-Baranja). The general numbers of tourist activity in four Croatian counties bordering with Hungary are not high and are still seeking to introduce selective types of tourism like the ones on the Croatian seaside. The data indicate that there are few tourists in the border region with Hungary, with little accommodation capacity and limited offer. In 2017, 195,297 tourists visited four counties on the Croatian side of the cross-border area while the number of tourist over-night stays was 418,090. Moreover, there is a lack of capacities for further development of tourism. In 2016, the total number of beds in all four counties was only 5359 and almost half of the capacities were in Osijek-Baranja County. In 2017, the total number of beds slightly increased, but not enough to support the development of tourism. Moreover, the number of beds in hotels in 2017 slightly fell compared to 2016.

Unlike the Croatian part of the border region, there are more significant capacities for the development of tourism in the Hungarian part of the border region. However, although the capacities are more significantly used, their number is falling. In 2017, the total number of beds in three counties decreased by almost $27 \%$, due to the decrease of capacities in Somogy by almost 30,000 beds. However, the entire Hungarian part of the border region in 2017 had 86,998 beds, out of which 32,958 were in hotels, which was 16 times more than on the Croatian side. Hungarian part of the border also attracted much more tourists than the Croatian part.

The gravity model was used to analyze tourist activity at the cross-border area in Croatia and Hungary bilaterally accompanying tourists from Croatia to Hungary and from Hungary to Croatia. The destination country was marked as $(j)$ and the origin country as $(i)$. The model was made for the period 2009-2018, where 2009 was the base year. Other two exogenous variables in the basic model were the Croatian and Hungarian GDP in the analyzed period. The expanded model, which included price variables that approximate tourist prices, had an additional two variables that, as already mentioned, compared prices in the origin country, destination country and alternative countries. The first price variable compared prices in Croatia and Hungary, using the Eurostat CPI (consumer price index) data and Hungarian National Bank and Croatian National Bank official exchange rates.

Exogenous variable distance $D_{i j}$ in the model represents the geographical distance between two capitals and economic centers, Zagreb and Budapest, even though they are not located in the cross-border area but have the strongest economic importance. 
The final model that explains Croatian tourist consumption in Hungary is given by:

$$
\ln T X_{i j t}=-17.1554 \ln Y_{i t}+19.3268 \ln Y_{j t}+21.6695 \ln P_{\kappa j t},
$$

which means that if the Hungarian GDP grows by $1 \%$, the amount of tourist consumption will fall by $17.16 \%$. If the Croatian GDP grows by $1 \%$, the expenditure will rise by $19.32 \%$, and if the prices in alternative destinations rise by $1 \%$, the expenditure in Hungary will rise by $21.67 \%$. All three variables were statistically significant at the significance level of $1 \%$. Centered R-squared was 0.85 , which means that $85 \%$ of the data were explained with the model. The $p$-value of the F-test was also statistically significant at the significance level of $1 \%$, while the Durbin-Watson test shows that there was no autocorrelation in the model.

To conclude, tourism in the Croatian-Hungarian cross-border region could be described using the FGLS model, but the distance was not a statistically significant variable. According to the analysis made for the period of ten years, 2009-2018, the number of Croatian tourists visiting Hungary depended on the Croatian GDP and prices in alternative destinations, while the expenditure of Croatian tourists in Hungary depended on both, the Croatian and Hungarian GDP and prices in alternative destinations.

In order to explain the number and expenditure of Hungarian tourists in Croatia, general variables, GDPs in both countries and distance were the same. The difference was in price variables. In the first price variable, where the prices in the origin country (Hungary) were compared with the prices in the destination country (Croatia), the difference was that the numerator and denominator were replaced. The second price variable compared prices in Croatia with alternative Hungarian destinations-Germany, Austria, Romania, Slovakia, Czech Republic, Italy, Serbia, the United States and other European Countries.

The final model for Hungarian tourist consumption looks as follows:

$$
\ln T X_{j i t}=-3.59965 \ln D_{t}+2.45084 \ln Y_{j t}+2.34042 \ln P_{j i t}+6.70164 \ln P_{\kappa j t} .
$$

The variables in the FGLS estimation model for consumption were the same as in the model for arrivals. The closer the destination was to the origin the expenditure was bigger. The most important for Hungarian tourist consumption was the price variable that compared prices in Croatia with alternative destinations. If that variable grows by $1 \%$, the expenditure of Hungarian tourists in Croatia will rise by $6.7 \%$. The adjusted R-squared shows that $98 \%$ of the data were explained with the model. The $p$-value of the F-test was statistically significant at the significance level of $1 \%$ and the Durbin-Watson test shows that there was no autocorrelation.

According to the FGLS estimation method, the distance between the origin and destination was very important for Hungarian tourists. However, that was not the case with Croatian tourists. When choosing the tourist destination, Croatian tourists did not compare prices in the destination country or in alternative destinations. On the other hand, those variables in the model were statistically significant for Hungarian tourists.

Based on the interviews, it might be concluded that the tourist activity in the Croatian-Hungarian border region was far less active and vivid than in the inner regions of these countries. Croatian tourists were highly interested in Baranya County's wine region (Villány and Siklós), the related Ördögkatlan Festival and the cultural sights and activities in Pécs. However, Croats strongly considered visiting Budapest, especially for shopping and for large-scale popular cultural events.

Hungarian tourists arriving to Croatia were focused on the sea, and their activities were not really seen elsewhere. The immediate border area on both sides was not considered as a tourism destination, however, there were potentials in ecotourism, nature tourism and thematic gastro-experiences.

The main premise of the previously mentioned BorderPass project was that an integrated, cross-border online platform would promote local tourism. However, sufficient resources and capacities are needed for the sustainable operation with a well-designed business model. In order to 
attract more tourists, other infrastructural developments are also needed, especially in transportation, accommodation and tourist management.

In order to come up with a highly functional, up-to-date and useful application with a lot of added value, a very strong long-term cooperation is needed between tourist agencies, institutions and relevant actors of the participating countries. Overcoming the challenges due to the underlying cultural differences is also necessary.

Giant platforms, apps and ICT solutions like TripAdvisor, booking.com, Google and Siri are extensively used by tourists. However, they do not promote any cross-border activities.

\section{Discussion}

Regardless of the selected tool or a combination of tools, participatory tourism planning further ensures sustainability since the local stakeholders are in support of such a plan. In the case of HR-HU cross-border cooperation, participatory planning as a stand-alone activity was primarily burdened with language barriers, but, as noted before, if conditions are prepared within EU projects, they can be overcome.

Another aspect that needs to be considered in the planning process of cross-border tourism development is its integration in the existing policies. The concept of integrated planning for sustainable development has its roots in integrated urban development and "comprises a system of interlinked actions, which seeks to bring about a lasting improvement in the economic, physical, social and environmental conditions of a city or an area within the city. The key to the process is 'integration', meaning that all policies, projects and proposals are considered in relation to one another. In this regard, the synergies between the elements of the plan should be such that the impact of the plan as a whole adds up to more than would the sum of the individual parts if implemented in isolation" [36]. Recent innovative policy-making and policy-implementation, regardless of the sector, are focused on integrated plans $[37,38]$, which is relatively new but still not a widely accepted governance framework, since it requires a paradigm shift in current policy planning. However, it is a desirable approach since it ensures sustainability and possibly fosters innovations.

The gravity model was used in this research to analyze tourist activity at the cross-border area in Croatia and Hungary, where destination country $i$ was Hungary and the origin country $j$ was Croatia. Exogenous variable distance $D_{i j}$ in the model represents the geographical distance between two capitals and economic centers, Zagreb and Budapest.

The expanded model, which includes price variables that approximate tourist prices, has the additional two variables that, as already mentioned, compare prices in the origin country, destination country and alternative countries.

The more complex variable is the one that compares prices in Hungary and alternative destinations. According to the research of the Croatian Institute for Tourism [39], the most popular foreign destinations among Croatian tourists are Bosnia and Herzegovina, Germany and Austria. Figure 2 shows the most popular tourist destinations. The data at the country level will be applied to the cross-border area due to the lack of data specific for the bordering regions.

Prices in those destinations were compared with Hungarian prices using the consumer prices index and exchange rate between Hungarian forint and alternative destination countries' currencies.

A gravity model used in the analysis was made in econometric software gretl and the tables presented in this paper were estimations made in the software. The first column in tables, the coefficient, shows the percentage change of the dependent variable if the independent variable changes for $1 \%$, while the last column, $p$-value, shows the statistical significance of each variable.

The feasible generalized least squares (FGLS) estimation method, where distance is used as a weight variable, for the period 2009-2018 shows that none of the variables was statistically significant in the model, which means that this model did not explain the total amount of Croatian tourists in Hungary. The results of the first, general model are shown in Table 4. 


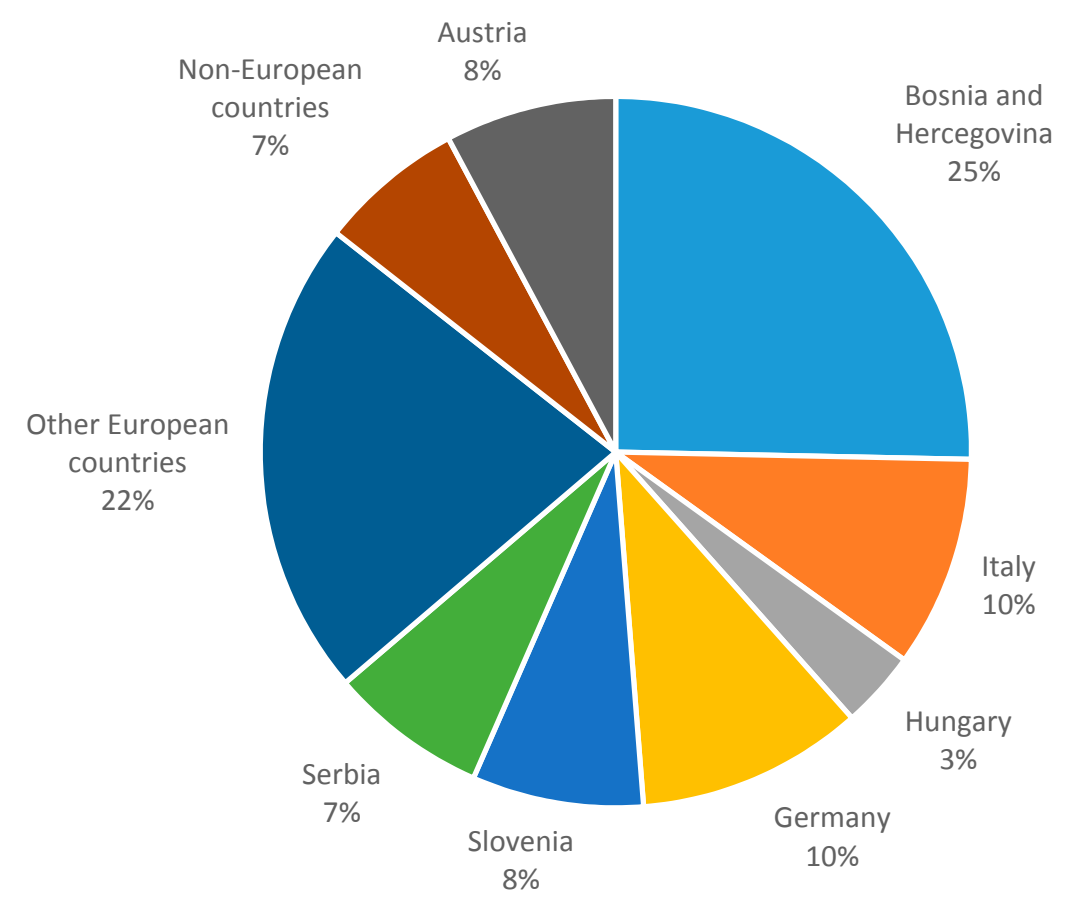

Figure 2. The most popular destinations among Croatian tourists [39].

Table 4. Feasible generalized least squares (FGLS) estimation of the total amount of Croatian tourists in Hungary-general model. Model 1: FGLS, using observations 2009-2018 ( $\mathrm{T}=10)$; dependent variable: TAij; variable used as weight: 1_Dt.

\begin{tabular}{ccccc}
\hline & Coefficient & Std. Error & t-Ratio & $p$-Value \\
\hline 1_Dt & -1184.98 & 1187.49 & -0.9979 & 0.3641 \\
l_Yi & -705.421 & 896.825 & -0.7866 & 0.4672 \\
l_Yj & 1472.62 & 1487.26 & 0.9902 & 0.3676 \\
1_Pijt & 102.320 & 2611.98 & 0.03917 & 0.9703 \\
l_PIjt & 1805.50 & 2739.09 & 0.6592 & 0.5389 \\
\hline \multicolumn{5}{c}{ Statistics based on the weighted data: } \\
\hline Sum squared resid & 104686.0 & S.E. of regression & 144.6969 \\
R-squared & 0.624512 & Adjusted R-squared & 0.324122 \\
F(4.5) & 2.079001 & $p$-value (F) & 0.221283 \\
\hline Log-likelihood & -60.47006 & Akaike criterion & 130.9401 \\
Schwarz criterion & 132.4531 & Hannan-Quinn & 129.2805 \\
Rho & -0.274012 & Durbin-Watson & 2.491975 \\
\hline \multicolumn{5}{c}{} \\
\hline Mean dependent var & 910.6000 & S.D. dependent var & 73.69939 \\
Sum squared resid & 18355.50 & S.E. of regression & 60.58961 \\
\hline
\end{tabular}

To describe the amount of Croatian tourists in Hungary, variables with the largest $p$-values were excluded from the model. The final model shows that only two variables were statistically significant at the significance level of $10 \%$, the Croatian GDP and prices in alternative destinations. The results of the FGLS estimation method are shown in Table 5.

According to the FGLS estimation, the unified gravity model for the Croatian-Hungarian cross-border tourism is given by:

$$
\ln T A_{i j t}=82.1707 \ln Y_{j t}+1171.60 \ln P_{\kappa j t},
$$


which means that if the Croatian GDP rises for $1 \%$, the number of Croatian tourists visiting Hungary will rise by $82.17 \%$. Moreover, if prices in alternative destinations rise by $1 \%$, the number of tourists visiting Hungary will rise by $1171.6 \%$.

Table 5. FGLS estimation of the total amount of Croatian tourists in the Hungary-final model. Model 2: FGLS, using observations 2009-2018 ( $\mathrm{T}=10)$; dependent variable: TAij; variable used as weight: 1_Dt.

\begin{tabular}{ccccc}
\hline & Coefficient & Std. Error & t-Ratio & $p$-Value \\
\hline 1_Yj & 82.1701 & 2.19123 & 37.50 & $<0.0001^{* * *}$ \\
1_Pkjt & 1171.60 & 553.776 & 2.116 & $0.0673 *$ \\
Sum squared resid & Statistics based on the weighted data: & \\
Uncentered R-squared & 166353.5 & S.E. of regression & 144.2019 \\
F(2.8) & 0.403323 & Centered R-squared & 0.403323 \\
Log-likelihood & 2.703795 & $p$-value (F) & 0.126753 \\
Schwarz criterion & 130.1768 & Akaike criterion & 129.5716 \\
Rho & 0.145540 & Hannan-Quinn & 128.9078 \\
& Statistics based on the original data: & 1.537400 \\
Mean dependent var & 910.6000 & S.D. dependent var & 73.69939 \\
Sum squared resid & 29168.19 & S.E. of regression & 60.38232 \\
\hline
\end{tabular}

However, the centered R-squared and $p$-value of the F-test show that even though the variables were statistically significant at the significance level of $10 \%$, this model did not explain the number of Croatian tourists visiting Hungary appropriately. The reason for this could be a short period of analysis of only ten years due to the lack of data. Moreover, the main variable in gravity models, distance, was not significant in this estimation.

In the case when exogenous variables were used to describe the tourist consumption, the model was more applicable. The general model that explained consumption, at the significance level of $10 \%$ had two statistically significant variables, the Croatian and the Hungarian GDP. The results are shown in Table 6.

Table 6. FGLS estimation of Croatian tourist consumption in Hungary-general model. Model 3: FGLS, using observations 2009-2018 ( $\mathrm{T}=10)$; dependent variable: 1_TXij; variable used as weight: 1_Dt.

\begin{tabular}{ccccc}
\hline & Coefficient & Std. Error & t-Ratio & $p$-Value \\
\hline 1_Yi & -17.8086 & 5.39153 & -3.303 & $0.0214^{* *}$ \\
I_Yj & 22.2399 & 8.94109 & 2.487 & $0.0553 *$ \\
1_Pijt & -0.310962 & 15.7027 & -0.01980 & 0.9850 \\
1_Pkjt & 20.8830 & 16.4668 & 1.268 & 0.2606 \\
1_Dt & -4.15326 & 7.13892 & -0.5818 & 0.5860 \\
& Statistics based on & the weighted data: & \\
Sum squared resid & 3.783529 & S.E. of regression & 0.869888 \\
R-squared & 0.873519 & Adjusted R-squared & 0.772334 \\
F(4.5) & 8.632895 & p-value(F) & 0.018114 \\
Log-likelihood & -9.329745 & Akaike criterion & 28.65949 \\
Schwarz criterion & 30.17242 & Hannan-Quinn & 26.99981 \\
Rho & -0.619177 & Durbin-Watson & 3.159839 \\
& Statistics based on the original data: & \\
Mean dependent var & 9.153983 & S.D. dependent var & 0.763402 \\
Sum squared resid & 0.663399 & S.E. of regression & 0.364252 \\
\hline
\end{tabular}

In this estimation, the biggest $p$-value had the variable exchange rate. When this variable was excluded out of the model, except for the distance, all of the variables were statistically significant at the significance level of one percent, as shown in Table 7. 
Table 7. FGLS estimation of Croatian tourist consumption in Hungary-model 2. Model 4: FGLS, using observations 2009-2018 ( $\mathrm{T}=10)$; dependent variable: 1_TXij; variable used as weight: 1_Dt.

\begin{tabular}{ccccc}
\hline & Coefficient & Std. Error & t-Ratio & $p$-Value \\
\hline 1_Yi & -17.8964 & 2.79761 & -6.397 & $0.0007^{* * *}$ \\
1_Yj & 22.3901 & 4.32612 & 5.176 & $0.0021^{* * *}$ \\
1_Pkjt & 21.1916 & 4.84714 & 4.372 & $0.0047^{* * *}$ \\
1_Dt & -4.25616 & $4.46910 \quad-0.9524$ & 0.3777 \\
& Statistics based on & the weighted data: & \\
Sum squared resid & 3.783825 & S.E. of regression & 0.794127 \\
R-squared & 0.873509 & Adjusted R-squared & 0.810263 \\
F(3.6) & 13.81139 & $p$-value(F) & 0.004212 \\
Log-likelihood & -9.330137 & Akaike criterion & 26.66027 \\
Schwarz criterion & 27.87062 & Hannan-Quinn & 25.33253 \\
Rho & -0.615540 & Durbin-Watson & 3.152865 \\
& Statistics based on the original data: & \\
Mean dependent var & 9.153983 & S.D. dependent var & 0.763402 \\
Sum squared resid & 0.663451 & S.E. of regression & 0.332528 \\
\hline
\end{tabular}

When distance was excluded out of the model, as an omit variable, the final model looked as in Table 8:

Table 8. FGLS estimation of Croatian tourist consumption in Hungary-final model. Model 5: FGLS, using observations 2009-2018 ( $\mathrm{T}=10)$; dependent variable: 1_TXij; variable used as weight: 1_Dt.

\begin{tabular}{ccccc}
\hline & Coefficient & Std. Error & t-Ratio & $p$-Value \\
\hline 1_Yi & -17.1554 & 2.66932 & -6.427 & $0.0004^{* * *}$ \\
1_Yj & 19.3268 & 2.87371 & 6.725 & $0.0003^{* * *}$ \\
1_Pkjt & 21.6695 & 4.78896 & 4.525 & $0.0027^{* * *}$ \\
& Statistics based on the & weighted data: \\
Sum squared resid & 4.355798 & S.E. of regression & 0.788833 \\
Uncentered R-squared & 0.854388 & Centered R-squared & 0.854388 \\
F(3.7) & 13.69101 & p-value(F) & 0.002583 \\
Log-likelihood & -10.03400 & Akaike criterion & 26.06800 \\
Schwarz criterion & 26.97575 & Hannan-Quinn & 25.07219 \\
Rho & -0.424635 & Durbin-Watson & 2.669740 \\
& Statistics based on the original data: & \\
Mean dependent var & 9.153983 & S.D. dependent var & 0.763402 \\
Sum squared resid & 0.763740 & S.E. of regression & 0.330312 \\
\hline
\end{tabular}

The final model that explained Croatian tourist consumption in Hungary was given by:

$$
\ln T X_{i j t}=-17.1554 \ln Y_{i t}+19.3268 \ln Y_{j t}+21.6695 \ln P_{\kappa j t} .
$$

The standard error of residuals, which is a statistical term used to describe the difference in standard deviations of observed values versus predicted values as shown by points in the regression analysis, shows that the set of data points mostly fit well with the model. The list of standard error of residuals is given in Table 9.

Table 9. Standard error of residuals. Model estimation range: 2009-2018; standard error of residuals = 0.330312 .

\begin{tabular}{cccc}
\hline & 1_TXij & Fitted & Residual \\
\hline 2009 & 8.3041 & 8.0174 & 0.286718 \\
2010 & 8.98042 & 9.23411 & -0.253688 \\
2011 & 9.05835 & 8.81204 & 0.246318 \\
\hline
\end{tabular}


Table 9. Cont.

\begin{tabular}{cccc}
\hline & 1_TXij & Fitted & Residual \\
\hline 2012 & 8.82541 & 8.92772 & -0.102304 \\
2013 & 8.71686 & 8.89311 & -0.176251 \\
2014 & 8.96661 & 9.00598 & -0.0393701 \\
2015 & 9.03801 & 9.00866 & 0.0293516 \\
2016 & 8.84491 & 9.41272 & -0.567803 \\
2017 & 8.98369 & 8.58311 & 0.400585 \\
2018 & 8.82144 & 8.64912 & 0.172312 \\
\hline
\end{tabular}

In the general model that estimated the number of Hungarian tourists in Croatia, there were only two statistically significant variables at the significance level of $5 \%$, distance and prices in Croatia. The results of the general model are shown in Table 10.

Table 10. FGLS estimation of total amount of Hungarian tourists in Croatia-general model. Model 1: FGLS, using observations 2009-2018 (T = 10); dependent variable: 1_TAji; variable used as weight: 1_Dt.

\begin{tabular}{ccccc}
\hline & Coefficient & Std. Error & t-Ratio & $p$-Value \\
\hline 1_Dt & -2.51878 & 0.728575 & -3.457 & 0.0181 ** \\
1_Yi & 0.534066 & 0.777478 & 0.6869 & 0.5227 \\
l_Yj & 1.97181 & 1.10519 & 1.784 & 0.1345 \\
1_Pjit & 2.78286 & 0.743475 & 3.743 & 0.0134 ** \\
1_Pkit & 4.27270 & 2.27749 & 1.876 & 0.1195 \\
& Statistics based on the weighted data: & \\
Sum squared resid & 0.056095 & S.E. of regression & 0.105920 \\
R-squared & 0.983263 & Adjusted R-squared & 0.969873 \\
F(4.5) & 73.43304 & p-value(F) & 0.000125 \\
Log-likelihood & 11.72710 & Akaike criterion & -13.45420 \\
Schwarz criterion & -11.94127 & Hannan-Quinn & -15.11387 \\
Rho & 0.021211 & Durbin-Watson & 1.653306 \\
& Statistics based on the original data: & \\
Mean dependent var & 12.87295 & S.D. dependent var & 0.255526 \\
Sum squared resid & 0.009836 & S.E. of regression & 0.044352 \\
\hline
\end{tabular}

The variable with the biggest $p$-value was the Hungarian GDP and when excluded out of the model, all variables were statistically significant at the significance level of $1 \%$. The results of the FGLS estimation method are shown in Table 11.

Table 11. FGLS estimation of the total amount of Hungarian tourists in Croatia - final model. Model 2: FGLS, using observations 2009-2018 ( $\mathrm{T}=10)$; dependent variable: 1_TAji; variable used as weight: 1_Dt.

\begin{tabular}{|c|c|c|c|c|}
\hline & Coefficient & Std. Error & t-Ratio & $p$-Value \\
\hline 1_Dt & -2.78593 & 0.588354 & -4.735 & $0.0032 * * *$ \\
\hline 1_Yj & 2.69672 & 0.313573 & 8.600 & $0.0001^{* * *}$ \\
\hline 1_Pjit & 3.09912 & 0.557478 & 5.559 & $0.0014^{* * *}$ \\
\hline 1_Pkit & 5.73546 & 0.771352 & 7.436 & $0.0003^{* * *}$ \\
\hline \multicolumn{5}{|c|}{ Statistics based on the weighted data: } \\
\hline Sum squared resid & 0.061389 & \multicolumn{2}{|c|}{ S.E. of regression } & 0.101151 \\
\hline R-squared & 0.981683 & \multicolumn{2}{|c|}{ Adjusted R-squared } & 0.972525 \\
\hline $\mathrm{F}(3.6)$ & 107.1885 & \multicolumn{2}{|c|}{$p$-value $(\mathrm{F})$} & 0.000013 \\
\hline Log-likelihood & 11.27619 & \multicolumn{2}{|c|}{ Akaike criterion } & -14.55239 \\
\hline Schwarz criterion & -13.34205 & \multicolumn{2}{|c|}{ Hannan-Quinn } & -15.88013 \\
\hline Rho & -0.157657 & \multicolumn{2}{|c|}{ Durbin-Watson } & 1.903119 \\
\hline \multicolumn{5}{|c|}{ Statistics based on the original data: } \\
\hline Mean dependent var & 12.87295 & \multicolumn{2}{|c|}{ S.D. dependent var } & 0.255526 \\
\hline Sum squared resid & 0.010764 & \multicolumn{2}{|c|}{ S.E. of regression } & 0.042355 \\
\hline
\end{tabular}


According to the FGLS estimation, the number of Hungarian tourists visiting Croatia was given by:

$$
\ln T A_{j i t}=-2.78593 \ln D_{t}+2.69672 \ln Y_{j t}+3.09912 \ln P_{j i t}+5.73546 \ln P_{\kappa j t} .
$$

To Hungarian tourists, distance was the important variable when choosing the tourist destination, the bigger the distance between the origin and tourist destination means the less Hungarian tourists will visit the destination. The growth of the Croatian GDP by $1 \%$ means $2.7 \%$ more Hungarian tourists, the growth in prices also affected the increase of the number of Hungarian tourists according to the estimation, as well as the growth in prices in alternative destinations. For example, if prices in Germany, Austria, Romania and other alternative destinations rise by $1 \%$, the number of Hungarian tourists visiting Croatia will rise by $5.7 \%$. The adjusted R-squared equaled 0.9725 , which means that $97 \%$ of the data were explained with the model. The $p$-value of the F-test was also statistically significant at the significance level of $1 \%$, while the Durbin-Watson test shows that there was no autocorrelation in the model.

The general estimation model for the expenditure of Hungarian tourists (see Table 12) also had one variable, the Hungarian GDP that was not statistically significant in the model. The Croatian GDP was significant at the level of $10 \%$, as were the price variables at $5 \%$ and only distance was statistically significant at the level of $1 \%$.

Table 12. FGLS estimation of Hungarian tourist consumption in Croatia - general model. Model 3: FGLS, using observations 2009-2018 ( $\mathrm{T}=10)$; dependent variable: 1_TXji; variable used as weight: 1_Dt.

\begin{tabular}{ccccc}
\hline & Coefficient & Std. Error & t-Ratio & $p$-Value \\
\hline 1_Dt & -3.53030 & 0.599895 & -5.885 & $0.0020^{* * *}$ \\
1_Yj & 2.26267 & 0.909996 & 2.486 & $0.0554^{*}$ \\
1_Pjit & 2.25832 & 0.612162 & 3.689 & $0.0142^{* *}$ \\
1_Pkit & 6.32191 & 1.87524 & 3.371 & $0.01999^{* *}$ \\
1_Yi & 0.138640 & 0.640160 & 0.2166 & 0.8371 \\
& Statistics based on the weighted data: \\
Sum squared resid & 0.038030 & S.E. of regression & 0.087212 \\
R-squared & 0.986924 & Adjusted R-squared & 0.976463 \\
F(4.5) & 94.34511 & $p$-value(F) & 0.000068 \\
Log-likelihood & 13.67047 & Akaike criterion & -17.34094 \\
Schwarz criterion & -15.82801 & Hannan-Quinn & -19.00061 \\
Rho & -0.045740 & Durbin-Watson & 1.729402 \\
& Statistics based on the original data: & \\
Mean dependent var & 5.503979 & S.D. dependent var & 0.238036 \\
Sum squared resid & 0.006668 & S.E. of regression & 0.036519 \\
\hline
\end{tabular}

When the Hungarian GDP was excluded out of the model, all of the variables left were statistically significant at the significance level of $1 \%$. The final model is shown in Table 13.

Table 13. FGLS estimation of Hungarian tourist consumption in Croatia - final model. Model 4: FGLS, using observations 2009-2018 ( $\mathrm{T}=10)$; dependent variable: 1_TXji; variable used as weight: 1_Dt.

\begin{tabular}{ccccc}
\hline & Coefficient & Std. Error & t-Ratio & $p$-Value \\
\hline 1-51_Dt & -3.59965 & 0.465248 & -7.737 & $0.0002^{* * *}$ \\
1_Yj & 2.45084 & 0.247962 & 9.884 & $<0.0001^{* * *}$ \\
1_Pjit & 2.34042 & 0.440832 & 5.309 & $0.0018^{* * *}$ \\
1_Pkit & 6.70164 & 0.609955 & 10.99 & $<0.0001^{* * *}$ \\
& Statistics based on the weighted data: & \\
Sum squared resid & 0.038387 & S.E. of regression & 0.079986 \\
R-squared & 0.986801 & Adjusted R-squared & 0.980202 \\
F(3.6) & 149.5307 & $p$-value(F) & $5.00 \mathrm{e}-06$ \\
\hline
\end{tabular}


Table 13. Cont.

\begin{tabular}{|c|c|c|c|}
\hline & Coefficient & Std. Error & $p$-Value \\
\hline $\begin{array}{c}1-5 \\
\text { Log-likelihood }\end{array}$ & 13.62378 & Akaike criterion & -19.24757 \\
\hline Schwarz criterion & -18.03723 & \multirow{2}{*}{$\begin{array}{l}\text { Hannan-Quinn } \\
\text { Durbin-Watson }\end{array}$} & -20.57531 \\
\hline Rho & -0.087845 & & 1.784394 \\
\hline \multicolumn{4}{|c|}{ Statistics based on the original data: } \\
\hline Mean dependent var & 5.503979 & S.D. dependent var & 0.238036 \\
\hline Sum squared resid & 0.006731 & S.E. of regression & 0.033493 \\
\hline
\end{tabular}

The final model for Hungarian tourist consumption looks as follows:

$$
\ln T X_{j i t}=-3.59965 \ln D_{t}+2.45084 \ln Y_{j t}+2.34042 \ln P_{j i t}+6.70164 \ln P_{\kappa j t} .
$$

Based on the interviews' results the findings show that altogether $72 \%$ of the tourists did cross the border during a trip to the HR-HU border regions. This proportion was a lot lower among Hungarians with an average of $52 \%$ cross-border visitors. The typical reason of not crossing the border was a lack of time and-among Hungarians-higher expenses, however, the ratio of those who did not visit the neighboring country due to a lack of information about programs and/or about places of interest was also considerable $(20 \%)$. Thus, any innovative communication tool that facilitated obtaining information about the region might stimulate crossing the border. Almost half of the respondents also planned and organized programs during the trip, this behavior being more prevalent with Hungarians $(56 \%)$. Collecting information during the trip was more difficult than before the trip, while before the trip only $14 \%$ of tourists had some difficulties with planning, during their visit $36 \%$ of them were facing problems when trying to obtain information. An easily accessible and well-structured online platform would unquestionably be a useful tool for tourists, especially during their journey.

The main source of collecting information about a trip were friends, family members and acquaintances $(43 \%)$, and all together $80 \%$ of the respondents also used at least one online tool for the planning, however using a travel mate mobile application was relatively rare $(10 \%)$. The usage distribution of the most prevalent online tools is listed in Table 14, together with the perceived usefulness.

Table 14. Proportion of users of the most prevalent online tools with perceived usefulness.

\begin{tabular}{ccc}
\hline & Used for Planning & Marked as Most Useful \\
\hline online collection sites & $35 \%$ & $9 \%$ \\
online articles, blogs, YouTube videos, etc. & $32 \%$ & $14 \%$ \\
online travel mates & $30 \%$ & $10 \%$ \\
homepage sites of the & $28 \%$ & $9 \%$ \\
region/settlements/counties & $27 \%$ & $8 \%$ \\
internet forums & $23 \%$ & $6 \%$ \\
social networks (Facebook, Instagram, & & \\
Twitter, etc.) &
\end{tabular}

Source: Authors, based on interviews.

The proportion of those visitors who had to abandon an activity due to the lack of information was relatively high (51\%), and this ratio was highest among the Croats (70\%) and among those, who also visited the neighboring country $(57 \%)$.

The most common unrealized goals were attending festivals or concerts $(20 \%$ of Croats and $10 \%$ of Hungarians) or sport events as spectators (15\% of Croats and $5 \%$ of Hungarians), or visiting exhibitions or fairs (14\% of Croats and 3\% of Hungarians) or attending programs for children (16\% of Croats and $5 \%$ of Hungarians).

The evaluation of presented features of an envisioned cross-border info-communication platform shows that the best liked features were information about accommodation, services, restaurants and 
places of interest, while the least attractive functions were collecting points for experience sharing (see Table 15).

Table 15. Evaluation of an envisioned cross-border information platform in a 1-5 Likert scale.

\begin{tabular}{ccc}
\hline Platform Features & Croatia & Hungary \\
\hline information about accommodation, services, restaurants and means of transport & 4.23 & 4.51 \\
information about places of interest & 4.14 & 4.43 \\
virtual thematic tours connected to the region & 4.19 & 4.38 \\
possibility to get prompt answer to questions & 3.91 & 3.78 \\
possibility to share experiences with others-a kind of community platform & 3.70 & 3.80 \\
collect points with online activity that can be transferred to discounts & 3.65 & 3.30 \\
\hline
\end{tabular}

Source: Authors, based on interviews.

Willingness to use such a cross-border online information platform was high, 35\% of the respondents would definitely visit it and an additional $40 \%$ indicated a probable use. Croats were a more receptive audience to the platform, with $84 \%$ claiming a probable or definite visit to the site. Willingness to use grows with education. Nearly two-thirds of people thought that the cross-border online platform would stimulate them to visit both parts of the border regions. A stronger effect could again be expected among Croats and within the youngest age segment (18-25 years old people).

\section{Conclusions and Recommendations}

Even though tourism in the Croatian-Hungarian cross-border area exists, it does not fulfill its potential estimated with the presented gravity model. The cross-border area has a great potential for tourism development. It can offer a lot of services such as recreation and sports, health tourism, cultural tourism, gastronomy and oenology, business tourism and ecotourism. However, the potential is not sufficiently recognized among tourists so the area does not record as many arrivals and overnight stays as other areas in the two countries. As the digitally connected planning mode is ever more prevalent during tourism activities and trips, the development of an ICT platform could improve this situation since it could present different types of regional tourism options and offers to interested visitors.

The gravity models used to describe the total number of tourist and their consumption in general show that distance was not a significant variable for Croatian tourists when choosing their destination. According to the model, the most important variable that explained the number of Croatian tourists was the Croatian GDP-if it rises for 1\%, the number of Croatian tourists in Hungary will rise for $82.17 \%$, and their consumption for $21.67 \%$. On the other hand, for Hungarian tourists, distance was an important variable when choosing their destination, as well as prices in alternative destinations. If prices in alternative destinations rise for $1 \%$, the number of Hungarian tourists in Croatia will on average rise for $5.7 \%$, while their consumption will rise for $6.7 \%$. According to the gravity models, there were no obstacles to the development of sustainable tourism in the Croatian-Hungarian cross-border area if tourists were provided with the content and availability of information of interest, which could be solved by introducing the digital platform.

In the era of digital transformation, one of the most important business models is the platform that integrates different services and attractions, collects and utilizes data that are the most important new raw material, and opens a completely new space for virtual tourism. Based on the collected data, deep learning-based artificial intelligence was capable to generate personalized customer journeys rich in potential positive experiences. The envisioned ICT platform would be able to offer enriched local tourism experiences both by personalized customer journey offers and digitally enhanced experiences of the attractions.

In view of overtourism, the sustainability considerations are also inevitable, thus quality improvement through offer personalization and virtual enhancement is very welcome instead of increasing quantity, so harms and negative effects of mass tourism can be avoided. The group concluded that from the different potential themes, vitality could be a viable focus of the Croatian-Hungarian 
cross-border platform, to be explored through nature, through human health and through cultural experiences. Properly designed content could also improve or, in other instances, even create a specific regional identity, which would substantially increase the participatory propensity among all stakeholder groups.

Focusing on the raw material to be exploited - the data, operational considerations and platform management are key issues for a long-term success. As richness, accuracy and validity of collected data are crucial for the envisioned platform functions, the different data layers should be carefully designed. For different country-specific legislation, there is a challenge to define a proper cross-border dataset and handle the variable legal and data management issues.

The conducted discussions with the stakeholders revealed that different border segments, especially between different countries might constitute diverse cooperation potentials. Readiness also could vary among the stakeholders, since it took three decades in the region to consider the neighborhood as an opportunity rather than a competitive situation.

Finally, from the users' perspective, the variety of information was of paramount importance. The recommendations for the development of the ICT concept addressed a complex and diverse client structure, since both business-to-business and multiple customer needs with widely diverse interests should be served. With the use of multiple information layers and well-designed algorithms, rather complex information sets could be utilized to meet special visitor expectations in orientation and experience enhancement.

Additionally, a strong language barrier could be solved by introducing the ICT platform in at least two local languages alongside English. Hungarian and Croatian are a very distinct group of languages and ICT tools can prove to be crucial in motivating travel. Moreover, the positive political climate with relatively long-standing history of solid relations between the two countries provides additional rationale for Hungarian-Croatian cross-border cooperation. Further development of tourism in the cross-border regions, however is dependent on the tourism infrastructure development since the existing one is not sufficient. Still, experience-related tourism offered by the proposed ICT platform can at the beginning count on authentic locally embedded experiences making use of the existing tourism infrastructure alongside private accommodation units. As it would potentially be packaged as a local cross-border experience, the joint efforts in designing diffused integrated hotels in the border regions together with the supporting infrastructure (e.g., bicycle and hiking trails), which would integrate the existing recreation, culture and vitality tourism-related assets is recommended. Conditions for that may be prepared with joint strategic and participatory activities as well as within EU projects.

Author Contributions: Conceptualization, D.A.J.; methodology and formal analysis (gravity model), I.T.; results and discussion S.T.; investigation, Z.L. and D.A.J.; resources, S.T., D.A.J. and Z.L.; writing-original draft preparation, D.A.J., S.T. and Z.L.; writing—review and editing, D.A.J., S.T. and Z.L.; visualization, I.T.

Funding: This research was co-funded by the Interreg Danube Transnational Program—Seed Money Facility under the call HUHR/1001 of the Hungary-Croatia Cross-border Cooperation Program, grant number DTP-SMF1-138, acronym: BorderPass. The APC was funded by the Institute for Development and International Relations, Zagreb, Croatia.

Conflicts of Interest: The authors declare no conflict of interest.

\section{References}

1. Rădulescu, C.M.; Pop, I.L. Promotion of cultural tourism through cooperation in the cross-border area. “Ovidius" Univ. Ann. Econ. Sci. Ser. 2017, 17, 51-56.

2. Tosun, C.; Timothy, D.J.; Parpairis, A.; MacDonald, D. Cross-border cooperation in tourism marketing growth strategies. J. Travel. Tour. Mark. 2005, 18, 5-23. [CrossRef]

3. Racz, Szilard. Main characteristics of Hungarian-Croatian political relations and cross-border co-operations. Available online: https://www.researchgate.net/publication/319414657_Main_characteristics_of_HungarianCroatian_political_relations_and_cross-border_co-operations/figures?lo=1 (accessed on 27 September 2019). 
4. Croatian Bureau of Statistics. Available online: https://www.dzs.hr/default_e.htm (accessed on 24 September 2019).

5. Hungarian Central Statistical Office. Available online: https://www.ksh.hu/?lang=en (accessed on 24 September 2019).

6. Vlada Republike Hrvatske. Strategija razvoja turizma Republike Hrvatske do 2020; godine. Ministarstvo turizma, Zagreb, Croatia; 2013. Available online: https://mint.gov.hr/UserDocsImages/arhiva/130426-Strategijaturizam-2020.pdf (accessed on 3 February 2019).

7. Tišma, S.; Jurlin, K.; Čermak, H. Obstacles to cross-border cooperation - case of Croatia and Hungary. Eur. J. Geogr. 2018, 9, 116-133.

8. Hungarian Tourism Agency. The National Tourism Development Strategy 2030: Executive Summary. Available online: https://mtu.gov.hu/documents/prod/mtu_strategia_2030-english.pdf (accessed on 15 January 2019).

9. Hungary-Croatia IPA Cross-Border Co-Operation Programme: Overview. Available online: http://www.huhr-ipa.com/en/overview (accessed on 14 January 2019).

10. Hungary-Croatia IPA Cross-border Co-operation Programme: Priorities. Available online: http://www.huhr-ipa.com/en/priorities (accessed on 14 January 2019).

11. Lopes, H.; Remoaldo, P.; Cadima Ribeiro, V.; Silva, S. The creation of a new tourism destination in low density areas: The Boticas Case. J. Spat. Organ. Dyn. 2016, 4, 118-131.

12. Timothy, J.D. Participatory planning-A view of tourism in Indonesia. Ann. Tour. Res. 1999, 26, 371-391. [CrossRef]

13. Mbaiwa, J.E.; Bernard, F.E.; Orford, C.E. Limits of acceptable change for tourism in the Okavango Delta. Tourism as a Sustainable Development Factor. Botsw. Notes Rec. 2008, 39, 98-112.

14. Buist, L.J.; Hoots, T.A. Recreation opportunity spectrum approach to resource planning. J. Forest. 1982, 80, 84-86.

15. Carroll, J.; Hession, K. Developing a tourism opportunity spectrum scale. J. Tour. Insights 2015, 6, 2. [CrossRef]

16. Boyd, S.W.; Butler, R.W. Managing ecotourism: An opportunity spectrum approach. Tour. Manag. 1996, 17, 557-566. [CrossRef]

17. Page, S.J.; Hall, C.M. Managing Urban Tourism; Prentice Hall: Harlow, England, 2003.

18. Wearing, S.; Archer, D. An 'interpretation opportunity spectrum': A new approach to the planning and provision of interpretation in protected areas. In CAUTHE 2003: Riding the Wave of Tourism and Hospitality Research; Braithwaite R., L., Braithwaite, W.R., Eds.; Southern Cross University: Lismore, NSW, Australia, 2003; pp. 1-18.

19. Morley, C.; Rosselló, J.; Santana-Gallego, M. Gravity models for tourism demand: Theory and use. Ann. Tour. Res. 2014, 48, 1-10. [CrossRef]

20. Khadaroo, J.; Seetanah, B. The role of transport infrastructure in international tourism development: A gravity model approach. Tour. Manag. 2008, 29, 831-840. [CrossRef]

21. Rey, B.; Myro, R.; Galera, A. Effect of low-cost airlines on tourism in Spain. A dynamic panel data model. J. Air. Transp. Manag. 2011, 17, 163-167. [CrossRef]

22. Fourie, J.; Santana-Gallego, M. The impact of mega-sport events on tourist arrivals. Tour. Manag. 2011, 32, 1364-1370. [CrossRef]

23. Priego, F.; Rosselló, J.; Santana-Gallego, M. The impact of climate change on domestic tourism: A gravity model for Spain. Reg. Environ. Change 2015, 15, 291-300. [CrossRef]

24. Gil-Pareja, S.; Llorca-Vivero, R.; Martínez-Serrano, J. The effect of EMU on tourism. Rev. Int. Econ. 2007, 15, 302-312. [CrossRef]

25. Ioannides, D.; Nielsen, P.Å.; Billing, P. Transboundary collaboration in tourism: The case of the Bothnian Arc. Tour. Geogr. 2006, 8, 122-142. [CrossRef]

26. Stoffelen, A. Tourism trails as tools for cross-border integration: A best practice case study of the Vennbahn cycling route. Ann. Tour. Res. 2018, 73, 91-102. [CrossRef]

27. Makkonen, T.; Williams, A.; Weidenfeld, A.; Kaisto, V. Cross-border knowledge transfer and innovation in the European neighbourhood: Tourism cooperation at the Finnish-Russian border. Tour. Manag. 2018, 68, 140-151. [CrossRef]

28. Huang, A. Influencing factors of China-Vietnam entry tourism based on gravitation model. Commer. Res. 2011, 9, 207-2011. 
29. Vietze, C. Cultural effects on inbound tourism into the USA: A gravity approach. Tour. Econ. 2012, 18, 121-138. [CrossRef]

30. Kosnan, S.; Ismail, N.; Kaliappan, S. Determinants of international tourism in malaysia: Evidence from gravity model. J. Ekon. Malays. 2013, 47, 131-138.

31. Butter, F.D.; Chasapopoulos, P.; Mihaylov, E. Demand for tourism in Greece: A panel data analysis using the gravity model. Int. J. Tour. Pol. 2014, 5, 173-191.

32. Eryiğit, M.; Kotil, E.; Eryiğit, R. Factors affecting international tourism flows to Turkey: A Gravity Model approach. Tour. Econ. 2010, 16, 585-595. [CrossRef]

33. Hanafiah, M.; Harun, M. Tourism demand in Malaysia: A cross-sectional pool time-series analysis. Int. J. Trade. Econ. Finance 2010, 1, 80-83. [CrossRef]

34. Yang, Y.; Wong, K. The influence of cultural distance on China inbound tourism flows: A panel data gravity model approach. Asian Geogr. 2012, 29, 21-37. [CrossRef]

35. Keum, K. Tourism flows and trade theory: A panel data analysis with the gravity model. Ann. Reg. Sci. 2010, 44, 541-557. [CrossRef]

36. European Investment Bank. What is an "Integrated Plan for Sustainable Urban Development"? Available online: http://www.eib.org/en/products/blending/jessica/faq/what-is-an-integrated-plan-for-sustainableurban-development.htm (accessed on 24 February 2019).

37. Jelinčić, D.A. Innovation in Culture and Development: The Culturinno Effect in Public Policy, 1st ed.; Palgrave Macmillan: Cham, Switzerland, 2017.

38. Jelinčić, D.A.; Mansfeld, Y. Applying cultural tourism in the revitalization and enhancement of cultural heritage: An integrative approach. In Cultural Urban Heritage-Development, Learning and Landscape Strategies, 1st ed.; Obad Šćitaroci, M.B., Bojanić Obad Šćitaroci, B., Mrđa, A., Eds.; Springer: Cham, Switzerland, 2019; pp. 35-43.

39. Institute for Tourism. Turistička aktivnost domaćeg stanovništva u 2013. godini/Tourist activity of Croatian population in 2013. 2013. Available online: http://www.iztzg.hr/UserFiles/file/TADS-2013.pdf (accessed on 1 January 2019).

(C) 2019 by the authors. Licensee MDPI, Basel, Switzerland. This article is an open access article distributed under the terms and conditions of the Creative Commons Attribution (CC BY) license (http://creativecommons.org/licenses/by/4.0/). 